\title{
ЕТАПИ СТАНОВЛЕННЯ ТВОРЧОЇ ДІЯЛЬНОСТІ ЮРІЯ ЄВСЮКОВА
}

\author{
Любов Голубцова ${ }^{1 \mathrm{a}}$, Сергій Плуталов ${ }^{2 a}$ \\ ${ }^{1}$ кандидат мистецтвознавства, доцент; \\ e-mail: golubtsova@i.ua; ORCID: 0000-0002-5807-2176 \\ 2 e-mail: si.plutalovv@gmail.com; ORCID:0000-0001-9155-5324 \\ а Луганська державна академія культури і мистецтв, Київ, Україна
}

\begin{abstract}
Анотація
Мета дослідження - розглянути та проаналізувати творчу спадщину актора театру й кіно Юрія Євсюкова. Методи дослідження. Історико-біографічний - для визначення основних етапів творчого зростання актора Ю. Євсюкова; хронологічний - для розкриття послідовності висвітлення творчих здобутків митця в наукових джерелах; аналітичний - під час дослідження особливостей акторського стилю Ю. Євсюкова в театральних виставах і кінострічках різних періодів. Наукова новизна полягає в тому, що вперше проаналізовано етапи становлення творчої спадщини актора Ю. Євсюкова й окреслено жанрово-стилістичні особливості його деяких ролей у театрі та в кіно. Висновки. У статті виокремлено важливі етапи творчої спадщини актора Ю. Євсюкова. Перший - робота в Луганському обласному академічному українському музично-драматичному театрі, де заклалися основи його акторського стилю. Тут актор опанував арсенал традиційних засобів сценічної виразності, переважно в межах комедійного жанру. Для другого періоду характерною $є$ співпраця з режисером О. Біляцьким, під час якої розкрилися нові грані обдарування митця, а саме здатність його психофізичного апарату до імпровізації. Третій - режисура А. Васильєва, що сприяла розвиткові навичок «текстової драматургії» та «текстової імпровізації» як форми «живого театру».
\end{abstract}

Ключові слова: Юрій Євсюков; творча спадщина; акторська діяльність; виконавська манера; театр

\section{Постановка проблеми}

Юрій Євсюков - актор, який синтезував у своїй діяльності традиційні та сучасні тенденції сценічного втілення художнього образу. Цим зумовлена актуальність обраної теми статті, яка передбачає необхідність узагальнити досвід акторського ремесла; визначити напрацювання та накопичення різних театральних шкіл, а саме традиційної (український музично-драматичний театр) і сучасних форм, що сформувалися наприкінці 80-х років XX століття та репрезентують практики реалістичного, модернового та постмодернового театру й кіно. 


\section{Аналіз останніх досліджень і публікацій}

у наукових дослідженнях акторська діяльність Ю. Євсюкова майже не висвітлена, а відтак відомості про діяльність актора здебільшого містяться в архівних матеріалах, кінострічках, артефактах, що знаходяться в Харківському краєзнавчому музеї, Харківському національному університеті мистецтв імені І. П. Котляревського та інших установах. Про виконавську практику митця також йдеться у рецензіях на вистави, що проходили в Харківському академічному російському драматичному театрі імені О. С. Пушкіна, театрі юного глядача; саме вони дають змогу зрозуміти становлення творчої особистості Ю. Євсюкова.

Серед наукових статей узагальненого характеру виокремлюємо статті О. Седунової в Енциклопедії сучасної України.

Науковим підґрунтям для осмислення особливостей акторського стилю Ю. Євсюкова на різних етапах його діяльності стали праці Н. Алексєєнко (1985), Л. Варницької (1982), В. Долганова (1983), Н. Єрмакової, Ю. Нечипоренко (1993), В. Фіалка (1983), в яких наведено аналіз специфіки та суті режисерських практик 1980-1990-х рр., а також сучасних дослідників, таких як А. Аннічев (2013; 2015), О. Мусієнко (2008), М. Сакаян (2008), О. Секішова (2013), Ю. Хомайко (2013). Та власні публікації Ю. Євсюкова (2014).

Мета статті - проаналізувати основні етапи творчості та формування індивідуальних рис, притаманних акторській практиці Ю. Євсюкова.

\section{Виклад основного матеріалу}

Юрій Степанович Євсюков - заслужений артист України (2007), народний артист України (2017), викладач Харківського національного університету імені І. П. Котляревського.

Народився 17 січня 1948 року в місті Улан-Уде (колишня Бурят-Монгольська АРСР, нині столиця Республіки Бурятії РФ). В акторську професію прийшов уже в зрілому віці. За свідченням Ю. Співака, студента курсу «Майстерня 55», у своїй лекції від 25.09.19. Ю. Євсюков згадував, що в самодіяльності ніколи не брав участі та й про акторську працю ніколи не мріяв. Ба більше, «театр» взагалі не подобався, оскільки вважав його штучним, нецікавим і неорганічним через «театральну» неправду. «Я загалом не любив театр. [...] В мене на першому місці як вища субстанція мистецтва музика. Потім живопис, потім проза, поезія, кіно і лише потім театр», - заявляв в інтерв'ю актор (Секишова, 2013). Згодом у подальших виступах митець наголошував на тезі, що «театр» має свої закони існування на сцені, проте далеко не всі бачать чіткий поділ між поняттями «мистецтво» та «штамп».

У 1969 році був запрошений працювати в Луганський обласний український музично-драматичний театр у ролі звукорежисера, збирався їхати на гастролі до Владивостока з мюзиклом «Сватання на Гончарівці», що був одним з найкращих репертуарних спектаклів. Ю. Євсюков згадував (за свідченнями Ю. Співака), що на одній з репетицій, у зв'язку з хворобою одного з акторів, режисер з відчаю попросив його стати на мізансцену в ролі Тимоша і сказати словоспо- 
Вісник Київського національного університету культури і мистецтв. Серія: Сценічне мистецтво

лучення «так-таки-так». Цей текст був єдиним у героя за всю виставу, але повторювався багато разів. У виконання цієї ролі актор привніс рухи, що зробили вимову тексту максимально органічною. Це сподобалося режисеру та всій трупі. Як згадував Ю. Євсюков, це було дуже комічно та в жанрі цієї вистави. Згодом Ю. Євсюков згадував, що з початку професійної кар'єри мріяв стати клоуном, а його кумиром на сцені був Юрій Нікулін. «Я любив з дитинства клеїти дурня, блазнювати, всіх веселити», - згадував Ю. Євсюков (Секишова, 2013).

Другий вихід на сцену відбувся у виставі «Циганка Аза», де актор-початківець сам виявив бажання взяти участь у виконанні однієї з епізодичних ролей. Досвід опанування акторської професії видався настільки вдалим, що в 1977 році його запросили працювати помічником режисера.

Значний вплив, як пригадував Ю. Євсюков, мала вистава «Безлюдний острів» (режисера О. Хропоченка), в якій він зіграв головну роль. Ця робота стала в житті актора доленосною, оскільки остаточно визначила його вибір: спиратися на власні природні здібності, займатися самотужки в розборі ролі та знаходити завдяки цим здібностям виразні засоби сценічного втілення.

Щодо процесу опанування акторської професії Ю. Євсюков, посилаючись на методику свого учителя Анатолія Васильєва, радив: «Щоб вийти на свою природу, треба спочатку спертись на когось. Однак не на західних, а на наших, слов'янських. Але однозначно ти не будеш ні Євстигнєєвим, ні Смоктуновським. Проте спертись внутрішньо, а потім вже вийти на свого в процесі роботи» (Секишова, 2013).

Додатковим важелем акторської майстерності Ю. Євсюкова стала також його робота в театрі освітлювачем і музичним оформлювачем. Після перегляду багатьох вистав він навчився розрізняти правду та брехню на сцені, нехай і на інтуїтивному рівні. Не подобалося йому, коли актори відверто вдають почуття, не наповнюють ролі, тому багато уваги звертав на органіку як засіб «ввімкнення» акторів у роботу, а реалізацією такого «ввімкнення» для нього ставав метод спостереження.

Форми для нього були різними, здебільшого це життєві спостереження: за партнером по виставі, за зміною свого внутрішнього та зовнішнього прояву почуття, за своїм станом від впливу прослуханої музики чи від перегляду улюбленого фільму тощо. Тільки за таких умов герої у виставі не будуть схожими, кожний зі своєю родзинкою, зі своїм «життєвим» стилем.

Важливими елементами таких спостережень також були ознаки зовнішності людей, їхня хода, тембр голосу, жести, манера виражати почуття, характеристики навколишнього світу (кольорові, предметні, тактильні), особливості людських психологічних станів та їхні внутрішні причини.

у 1980 році сім'я Ю. Євсюкова переїжджає до Харкова, де працював відомий театр юного глядача під керівництвом Олександра Беляцького. Тоді Галина, дружина Ю. Євсюкова, яка була професійною акторкою, попросила чоловіка підіграти їй на пробах до ТЮГу. Творчий дебют виявився вдалим - їх обох запросили до театру.

Однією з перших вистав була комедія для старшокласників «Гуманоїд в небі мчить» О. Хмелика, де Ю. Євсюков зіграв дядю Колю, простого, завжди трохи 
напідпитку чоловіка, який весь час втручається в життя школи та робить спроби розв'язати по-своєму моральні проблеми виховання підлітків.

Однією з визначних ролей цього періоду стала також роль загарбникафашиста у виставі «Запитай колись у трав» (за мотивами п'єси українського драматурга Я. Стельмаха). В її інтерпретації режисер О. Беляцький скористався особливостями акторської гри Ю. Євсюкова, а саме віртуозним володінням умовними прийомами музично-пластичної виразності.

Вистава «Запитай колись у трав», на думку Л. Варницької (1982, с.2), «носила форму ритмопластичної дії, де не лише музика, але й пластика, світло, колір несли емоційні, сюжетні і навіть філософські навантаження. При загальній єдиній гармонії усіх виразних засобів».

Інший погляд подає Н. Алексєєнко (1985, с.2), де звертає увагу на образну палітру вистави та зазначає, що втілений образ-уособлення фашизму Ю. Євсюкова яскраво продемонстрував низьке, боягузливе, мерзотне, одним словом, усе те, що хоче заховатися на дні людської душі.

Критики Н. Єрмакова та В. Фіалко $(1983$, с.13) також підкреслюють, що «символ фашизму, створений Ю. Євсюковим, [...] сприймається не тільки як його узагальнення, а й в ньому простежуються ще психологічні долі тих характерів, з якими це явище асоціюється». Розумного та тонкого ворога показує актор протягом усієї дії, який чудово знається на психології людської слабкості. У своїй статті журналіст В. Долганов зазначає:

«Вміло умовляє, тобто по-доброму, і залякує, він лише один раз зривається на істеричний крик - коли розуміє, що всі його спроби марні, а знання - нікчемні, що цих людей, вихованих новим світом, йому не дано не тільки перемогти, а й зрозуміти, що вони, розстріляні, повішені, скинуті у шурфи, житимуть віки у серцях і пам'яті багатьох поколінь». (Долганов, 1983, с.3)

Власне, нагадуванням про цю істину завершується вистава. Журналіст також зазначав, що «ця вистава вдало пройшла випробування не тільки перед глядачем, а й завоювала друге місце на республіканському фестивалі театральних творів для дітей та юнацтва. Актора Ю. Євсюкова було відзначено першим дипломом "за краще виконання чоловічої ролі"» (Долганов, 1983, с.3).

Як зазначає Р. Гнатишин (1982, с.3), Ю. Євсюков у цій виставі «намагався створити складний образ дволикого звіра в людській подобі, що ставав жорстким циніком, апологетом фашизму».

Акторка Т. Петровська, яка працювала в цих виставах у партнерстві з Ю. Євсюковим, розповідала, що «від природи дуже органічний, самобутній і яскравий він актор» (Нечипоренко, 1993, с.5). Вважала, що в нього вже від початку був хист і талант до акторського мистецтва такий, що особливо навчатися і не потрібно було. Він уже прийшов до театру як вдумливий актор, який вдало аналізував персонажів, зважаючи на життєвий досвід, вносив свою органіку й шукав правди існування на сцені (Нечипоренко, 1993, с.6).

Актор Ю. Євсюков стимулював свій творчий пошук під керівництвом О. Беляцького, що відбувався на рівні інтуїції та підсвідомості, а це своєю чергою сприяло пробудженню особливостей його акторської природи, відкриттю нових 
Вісник Київського національного університету культури і мистецтв.

Серія: Сценічне мистецтво

можливостей для його таланту. Специфіка праці в дитячому театрі спонукала його до імпровізації, яка вплинула на подальшу акторську долю, а також дала поштовх до спроб у режисурі, більш зрілого розуміння акторської професії.

У 1983 році режисер О. Беляцький перейшов працювати до Харківського державного академічного українського драматичного театру ім. Т. Г. Шевченка та запросив Ю. Євсюкова та його дружину. Але на цій сцені відсутність професійної освіти стала серйозною перешкодою, тому актор замислився над необхідністю отримати професійну режисерську освіту, вступивши на заочне відділення Російського театрального інституту мистецтв ім. А. В. Луначарського (нині Російський університет театрального мистецтва), за фахом «акторська майстерність» (викладачі: М. Захаров, А. Васильєв) (Евсюков, 2014, с. 418).

На лекціях, які відвідував Ю. Євсюков, народний артист, педагог Марк Захаров звертав увагу студентів на те, що «актору потрібно в сцені робити "коридори" та різкі “повороти", змінювати структуру акторського існування, тобто щоб не було прямих, довгих, сумних, діалогічних ліній, створювати живу тканину людського життя». Через рік М. Захаров передав свій курс режисеру, педагогу, заслуженому діячу мистецтв Анатолію Васильєву, котрий навчався в актриси, доктора мистецтвознавства М. Кнебель, учениці К. Станіславського, яка все своє творче життя сповідувала та розвивала метод дієвого аналізу (Евсюков, 2014, с.417).

А. Васильєв навчав студентів, «що в театрі завжди повинна бути жорстка дисципліна та самоконтроль, прагнув до театру філософського ("театру ідей")» (Агеев, 1995, с.23). Основними складовими його творчого методу є:

- подолання психологічних структур на основі імпровізації та гротеску (за методами Всеволода Меєрхольда);

- інтелектуальний підхід: формування смаку, поетичного та філософського початку у світогляді артистів;

- філософсько-алегоричний підхід;

- підхід генетичного виявлення природи театру: захоплення архаїчними формами, ритуалами, обрядами, використання гекзаметра, захоплення ідеями поліфонічності театру, концептуальним розбором драми;

- калокагатійний підхід, що має на меті гармонійне поєднання зовнішніх і моральних чеснот, досконалість людської особистості як ідеал виховання людини; лабораторний підхід (на основі ідей Є. Гротовського) (Васильев, 2003).

Як зазначав сам актор у своїй статті, то його вчитель А. Васильєв приділяв значну роль почуттям, хотів «виховати актора вільного, який переживає, внутрішньо відчуває, який грає структурно, усвідомлюючи, що є метою постановки; поета ролі, учасника метафоричного простору дійсності» (Евсюков, 2014, c.418). Наголошував, що актор «повинен не "грати роль", а "грати з роллю", тобто з персонажем, існувати в структурі вистави та зберігати при цьому свою індивідуальність» (Евсюков, 2014, с.417). Згадував також, що А. Васильєв постійно направляв їх до того, щоб

«...вони займалися внутрішнім світом персонажа, намагалися проживати чуже життя, не ілюструвати, не показувати, не зображати, а проживати; працювати з акторами до крику, до скандалу, ледь не до бійки, але домагалися того, що потрібно; чітко розподілити ролі, 
якщо актор технічно не досить здатний, тоді потрібно всіма методами витягнути, домогтися від цього актора того, що задумано в даній акторській роботі». (Васильєв, 2003)

У 1987 році відкрився експериментальний театр-студія «Школа драматичного мистецтва» («Школа драматического искусства») під керівництвом А. Васильєва, що працював в основному як лабораторія, де режисер разом з акторами займався довгим, наполегливим і складним методологічним пошуком у царині «ігрового театру». За роки перебування актор заявив себе в резонансній роботі «Біси» за мотивами роману Ф. Достоєвського, в якому Ю. Євсюков зіграв роль Кирилова, людини, котра вважає, що за допомогою самогубства стане боголюдиною і йде на підступні плани Верховинського (Васильев, 1995, с.94).

Ю. Євсюков згадував: «Працюючи над виставою "Шість персонажів у пошуках автора" за п'єсою Л. Піранделло, ми, студенти, зробили 800 екзерсисів!» Це був метод дієвого аналізу, який передбачав розбір п'єси за допомогою етюдів (А. Васильєв називав ці етюди екзерсисами). Виставу зіграли на численних європейських фестивалях та відзначили престижними преміями, зокрема «Призом за кращу постановку сезону» в Барселоні в 1988 році (Евсюков, 2014, с.418).

Незважаючи на великий досвід, здобутий Ю. Євсюковим, він приймає непросте рішення піти з театру «Школа драматичного мистецтва» («Школа драматического искусства») і повернутися до Харкова. Цей старт подарував йому багато різнопланових ролей у кінострічках і запрошення до режисерсько-педагогічної діяльності в Харківському національному університеті мистецтв ім.І. П. Котляревського, де продовжував розвивати художні принципи, естетику, методи роботи зі студентами, технології створення вистав, опановані під час роботи з А. Васильєвим.

Як зазначала член-кореспондент АМУ, кандидат мистецтвознавства, професор О. Мусієнко (2008, с.54), то його секрет як актора полягає в тому, що він «примудрявся поєднувати в собі глибину професійних суджень та дитячу безпосередність». Наводить, як приклад, виставу-трагікомедію «Дуже проста історія» за мотивами твору актриси, сценариста, драматурга, члена Національної спілки кінематографістів України Марії Ладо, прем'єра якої відбулася 8 березня 2008 року в Харківському державному академічному українському драматичному театрі ім. Т. Г. Шевченка (режисер та автор музичного оформлення - заслужений артист України А. Бакіров). У ній Ю. Євсюков «приголомшив глядачів "одкровенням людської долі", граючи роль доброго сусіда, який опинився здатним віддати своє життя, щоб дати шанс жити іншій людині» (Мусієнко, 2008, с.55).

Вистава викликає розуміння, що актор готовий кинутися «в вогонь і в воду», настільки бурхливо проявляється його енергетика на сцені та доноситься в зал. Бореться за свою правоту, проявляє це навіть фізично, що аж червоніє і «закипає». Цей стан може виявлятися, коли рівень присвоєння запропонованих обставин і рівень проживання проходить по потрібній межі. У цій ролі чітко відображає активне мислення, яке транслюють очі, обличчя, рухи; помітна розвиненість пам'яті фізичних дій, особливо це проявляється в реакції (коли його герой випиває горілку). Знову не можна не помітити його трагікомічну побудову ролі, якою він доводить глядачів до сліз. Як аналізує М. Сакаян (2008, с.14), «це 
Вісник Київського національного університету культури і мистецтв.

Серія: Сценічне мистецтво

людина з доброю душею, хоче постійно всім допомогти, а робить (ненавмисно) все тільки гірше, він є самою безгрішною людиною у п'єсі». У цьому відчувається глибокий сенс вистави. У його героя помітний характерний жест, що постійно повторюється (підтягування штанів «ледь не до вух»), і це неабияк доповнює образ персонажа. У техніці мови актора також $є$ переваги: він використовує широкий діапазон свого голосу у відтворенні характерного голосу персонажа, знаходить і наділяє персонажа характерними лише йому звуками, намагається доносити текст чітко та голосно. Якщо порівнювати з його партнерами по сцені у цій виставі, то в нього бачимо ввімкнення в запропоновані обставини п'єси та ролі протягом усього спектаклю, він проживає кожну секунду, унаслідок чого в глядачів з'являється співпереживання до героя у тому сенсі, що він міцно приковує увагу до себе і глядачам хочеться бути разом з ним в цей момент і в цю хвилину (Сакаян, 2008, с.14).

На думку критика Ю. Хомайко (2008), роль Круглика в «Законі» В. Винниченка актор зіграв «в ексцентричній манері, що переходить місцями в клоунаду, однак за всіма екстравагантними ескападами фабриканта-мільйонера простежується невлаштованість в особистому житті, трепетливе кохання до заміжньої жінки, і - додає автор, - важко не посвічувати Круглику, який переживає гострий біль від розчарування жінкою, яку він боготворив». Роль створена за допомогою образу-маски, що керується принципами сценічного гротеску. Цей метод зумовлює гіперболізацію характерних рис та умовність поведінки персонажа.

Харківський театральний критик О. Аннічев $(2013$, с. 12) аналізував телесеріал «Пристрасті за Чапаєм», що є екранізацією книги Е. Володарського, режисера С. Щербина, і зазначав, що роль батька Івана Чапаєва, яку зіграв Ю. Євсюков, «є вдумливою роботою з проникливим, навіть трагічним, усвідомленням простим мужиком абсурдності соціальних змін, за які віддають життя його сини». Ця роль справді відкрила його як актора, котрий вправно проживає жанр трагедії. У нього багато великих планів, в яких він безперечно як живий, тому його слова про смерть синів звучать дуже болісно. У картині відзначаємо максимальну наповненість актора, який тримається до останнього заради свого єдиного живого сина Чапая, як зазначав О. Аннічев (2013).

Деякі відомі ролі в театрі: Клим («Гроші» за п'єсою «Сто тисяч» І. КарпенкаКарого); Степан Бобиль («Млин щастя» за п'єсою В. Мережка «Пролетарський млин щастя»); Лопахін («Вишневий сад» А. Чехова); Йосип («Ревізор» М. Гоголя); Батько («Шестеро персонажів у пошуках автора» Л. Піранделло); Лікар («Дорогоцінна Памела» Дж. Патрика) та ін.

На телебаченні та в кіно відомий за ролями в серіалах, телепроєктах і фільмах, а саме: «УВС. Курс молодого бійця» (реж. В. Чичкун), «Маршрут милосердя» (реж.: О. Масленніков, С. Курбанов, М. Мокрушев, Бата Недич), «Заручники страху» (реж. О. Візир), «Голий» (реж. Г. Шигаєва), «Руда фея» (реж. В. Коваленко), «Ніагара» (реж. О. Візир), «Вперед, за скарбами гетьмана!» (реж. В. Кастеллі), «Дорога на Січ» (реж. С. Омельчука), «Тупік» (реж. Г. Кохан), «День переможених» (реж. В. Ямбурський), «Маршрути долі» (реж. І. Сауткін) та багато інших (Евсюков, 2021).

Наукова новизна. Уперше в сучасному мистецтвознавстві досліджено етапи становлення творчої спадщини представника Харківської акторської школи 
Ю. Євсюкова, розглянуто його внесок у розвиток сучасного українського театру, схарактеризовано особливості творчої манери в сценічних інтерпретаціях художніх образів, а саме: тяжіння до імпровізації, досконале володіння ритмопульсом драматичного характеру в концепції вистави, тяжіння в таких утіленнях до органічних практик, наближених до ігрових форм, пов'язаних з трансляцією універсальних життєвих смислів.

\section{Висновки}

Вивчення сучасних українських акторських практик $€$ актуальним для театральної науки. Такі дослідження дають змогу скласти уявлення про розвиток театрального мистецтва в його регіональних вимірах, що становить підґрунтя для осучаснення теорій акторської та режисерської майстерності в узагальнених вимірах. Аналіз діяльності конкретних персоналій на етапі їх творчого становлення дає змогу визначити загальнокультурні тенденції історичного та конкретно-ситуативного плану, пов'язані як з діяльністю окремих театральних інститутів, так і актуальних для театрального життя художніх ідей, естетичних ідеалів.

\section{СПИСОК ПОСИЛАНЬ}

Агеев, В., 1995. Об Анатолии Васильеве. Московский наблюдатель, 3-4, с.23.

Алексєєнко, Н., 1985. Юність спалена війною. Вільна Україна, 100, с.3.

Анничев, А., 2013. Приключения Чапая в тылу врага и на фронте любви. Live Journal. [online] Доступно: <http://annichev.livejournal.com/9973.html> [Дата звернення 28 січня 2021].

Анничев, А., 2014. «Волки и овцы» XXI века. Время, 2 декабря, с.7.

Варницька, Л., 1982. I ти запитай у трав. Вечерній Харьків, 21 грудня, с. 15-19.

Васильев, А., 1995. Дневник (парижского) режиссера. Искусство кино, 18, с.94.

Васильев, А., 2003. Школа злословия: Анатолий Васильев. [видео онлайн] Доступно: <https://www.youtube.com/watch?v=ASPk7T9mvYA> [Дата обращения 29 марта 2021].

Гнатишин, Р., 1982. Недописаний вірш. Вечірній Харків, 20 грудня, с.3.

Долганов, В., 1983. $€$ початок у подвигу і немає кінця. Соціалістична Харківщина, 4 лютого, с.3. Евсюков, Ю., 2014. Метод действенного анализа в процессе обучения студентов - будущих актеров. Проблеми взаємодії мистецтва, педагогіки та теорії і практики освіти, 39, c.414-421. Евсюков, Ю., 2015. Биография. Persona grata. [online] Доступно: <http://perta.ru/person/ evsyukov> [Дата обращения 19 марта 2021].

Евсюков, Ю., 2021. Фильмография. Кино-Театр. Ру. [online] Доступу: <https://www.kinoteatr.ru/kino/acter/m/sov/7739/works/> [Дата обращения 14 мая 2021].

Єрмакова, Н. та Фіалко, В., 1983. Значного явища значний характер. Культура і життя, 9, с.13. Мусієнко, О., 2008. Михайло Іллєнко (До 60-річчя від дня народження). Актуальні проблеми мистецької практики і мистецтвознавчої науки, 1, с.54-57.

Нечипоренко, Ю., 1993. Комісар Мегре Юрія Євсюкова. На екранах України, 23 квітня, с. 6-8. Сакаян, М., 2008. Бенефіс заслуженого артиста України Ю. С. Євсюкова з нагоди його 60-річчя на сцені Харківського державного академічного драматичного театру ім. Т. Г. Шевченка. Прес-реліз, 17 січня, с.14. 
Седунова, О., 2017. Євсюков Юрій Степанович. Енциклопедія Сучасної України: електронна версія. [online] Доступно: <http://esu.com.ua/search_articles.php?id=17424> [Дата звернення 10 березня 2021].

Секишова, Е., 2013. Путь к живому театру Юрия Евсюкова. Арт-мозаика, 3(814).

Хомайко, Ю., 2008. Озорной Евсюков. Нова демократія, 25 січня.

Хомайко, Ю., 2013. Трагикомические герои Юрия Евсюкова. Харьковские известия, 25 января, с. 18.

\section{REFERENCES}

Ageev, V., 1995. Ob Anatolii Vasileve [About Anatoly Vasiliev]. Moskovskii nabliudatel, 3-4, p.23. Aleksieienko, N., 1985. Yunist spalena viinoiu [Youth burned by war]. Vilna Ukraina, 100, p.3.

Annichev, A., 2013. Prikliucheniia Chapaia v tylu vraga i na fronte liubvi [The Adventures of Chapay behind enemy lines and on the front of love]. LiveJournal. [online] Available at: <http:// annichev.livejournal.com/9973.html> [Accessed 28 January 2021].

Annichev, A., 2014. "Volki i ovtcy" XXI veka ["Wolves and Sheep" XXI century]. Vremia, 2 December, p.7. Dolhanov, V., 1983. Ye pochatok u podvyhu i nemaie kintsia [There is a beginning in a feat and there is no end]. Sotsialistychna Kharkivshchyna, 4 February, p.3.

Evsiukov, lu., 2014. Metod deistvennogo analiza v protcesse obucheniia studentov - budushchikh akterov [The method of effective analysis in the process of teaching students - future actors]. Problemy vzaiemodii mystetstva, pedahohiky ta teorii i praktyky osvity, 39, pp.414-421.

Evsiukov, lu., 2015. Biografiia [Biography]. Persona grata. [online] Available at: <http://perta.ru/ person/evsyukov> [Accessed 19 March 2021].

Evsiukov, lu., 2021. Filmografiia [Filmography]. Kino-Teatr. RU. [online] Available at: <https:// www.kino-teatr.ru/kino/acter/m/sov/7739/works/> [Accessed 14 May 2021].

Hnatyshyn, R., 1982. Nedopysanyi virsh [Unwritten poem. Evening Kharkiv]. Vechirnii Kharkiv, 20 December, p.3.

Khomaiko, lu., 2013. Tragikomicheskie geroi Iuriia Evsiukova [Tragicomic heroes of Yuri Evsyukov]. Kharkovskii izvestiia, 25 January, p. 18.

Khomaiko, Yu., 2008. Ozornoi Evsiukov [Naughty Evsyukov]. Nova demokratiia, 25 January.

Musiienko, O., 2008. Mykhailo Illienko (Do 60-richchia vid dnia narodzhennia) [Mykhailo Ilyenko (To the 60-th anniversary of his birth)]. Aktualni problemy mystetskoi praktyky i mystetstvoznavchoi nauky, 1, pp.54-57.

Nechyporenko, Yu., 1993. Komisar Mehre Yuriia Yevsiukova [Commissioner Megre Yuri Yevsyukov]. Na ekranakh Ukrainy, 23 April, pp.6-8.

Sakaian, M., 2008. Benefis zasluzhenoho artysta Ukrainy Yu. S. Yevsiukova z nahody yoho 60-richchia na stseni Kharkivskoho derzhavnoho akademichnoho dramatychnoho teatru im. T. H. Shevchenka [Benefit of the Honored Artist of Ukraine Yu. S. Yevsyukov on the occasion of his 60th birthday on the stage of the Kharkiv State Academic Drama Theatre. T.G. Shevchenko]. Pres-reliz, 17 January, p.14.

Sedunova, O., 2017. Yevsiukov Yurii Stepanovych [Yevsyukov Yuriy Stepanovych]. Entsyklopediia Suchasnoi Ukrainy: elektronna versiia. [online] Available at: <http://esu.com.ua/search_articles. php?id=17424> [Accessed 10 March 2021].

Sekishova, E., 2013. Put k zhivomu teatru luriia Evsiukova [The path to Yuri Evsyukov's live theatre]. Art-mozaika, 28 January, p.2. 
Sekishova, E., 2013. Put k zhivomu teatru luriia Evsiukova [The path to the live theatre of Yuri Evsyukov]. Art-mozaika, 3(814).

Varnytska, L., 1982. I ty zapytai u trav [And you ask the herbs]. Vechernyi Kharkov, 21 December, pp.15-19.

Vasilev, A., 1995. Dnevnik (parizhskogo) rezhissera [Diary of a (Parisian) director]. Iskusstvo kino, 18, p.94.

Vasilev, A., 2003. Shkola zlosloviia: Anatolii Vasilev [School of slander: Anatoly Vasiliev]. [video online] Available at: <https://www.youtube.com/watch?v=ASPk7T9mvYA\&> [Accessed 29 March 2021].

Yermakova, N. and Fialko, V., 1983. Znachnoho yavyshcha znachnyi kharakter [Significant phenomenon is significant in nature]. Kultura i zhyttia, 9, p.13.

\title{
ЭТАПЫ СТАНОВЛЕНИЯ ТВОРЧЕСКОЙ ДЕЯТЕЛЬНОСТИ ЮРИЯ ЕВСЮКОВА
}

\author{
Любовь Голубцова ${ }^{1 a}$, Сергей Плуталов²а \\ ${ }^{1}$ кандидат искусствоведения, доцент; \\ e-mail: golubtsova@i.ua; ORCID: 0000-0002-5807-2176 \\ 2 e-mail: si.plutalovv@gmail.com; ORCID: 0000-0001-9155-5324 \\ а Луганская государственная академия культуры и искусств, Киев, Украина
}

\begin{abstract}
Аннотация
Цель исследования - рассмотреть и проанализировать творческое наследие актера театра и кино Юрия Евсюкова. Методы исследования. Историко-биографический - для определения основных этапов творческого роста актера Ю. Евсюкова; хронологический для раскрытия последовательности освещения творческих достижений мастера в научных источниках; аналитический - при исследовании особенностей актерского стиля Ю. Евсюкова в театральных спектаклях и фильмах разных периодов. Научная новизна заключается в том, что впервые проанализированы этапы становления творческого наследия актера Ю. Евсюкова и обозначены жанрово-стилистические особенности его некоторых ролей в театре и в кино. Выводы. В статье выделены важные этапы творческого наследия актера Ю. Евсюкова. Первый - работа в Луганском областном академическом украинском музыкально-драматическом театре, где были заложены основы его актерского стиля. Здесь актер овладел арсеналом традиционных средств сценической выразительности, преимущественно в пределах комедийного жанра. Второй период характеризуется сотрудничеством с режиссером А. Беляцким, во время которого раскрылись новые грани дарования мастера, а именно способность его психофизического аппарата к импровизации. Третий - режиссура А. Васильева, способствующая развитию навыков «текстовой драматургии» и «текстовой импровизации» как формы «живого театра».
\end{abstract}

Ключевые слова: Юрий Евсюков; творческое наследие; актерская деятельность; исполнительская манера; театр 


\title{
THE FORMATION STAGES OF YURII YEVSIUKOV'S CREATIVE ACTIVITY
}

\author{
Liubov Holubtsova1a, Serhii Plutalov²a \\ ${ }^{1}$ PhD in Art Studies, Associate Professor; \\ e-mail: golubtsova@i.ua; ORCID: 0000-0002-5807-2176 \\ 2 e-mail: si.plutalovv@gmail.com; ORCID: 0000-0001-9155-5324 \\ a Luhansk State Academy of Culture and Arts, Kyiv, Ukraine
}

\begin{abstract}
The purpose of the article is to consider and analyse the creative heritage of theatre and film actor Yurii Yevsiukov. Research methodology. Historical and biographical methods are used to determine the main stages of creative growth of the actor Yu. Yevsiukov; the chronological method is applied to reveal the sequence of coverage of the artist's creative achievements in scientific sources; the analytical method is used to study the features of the acting style of Yu. Yevsiukov in theatrical performances and films of different periods. The scientific novelty lies in the fact that for the first time the stages of formation of the creative heritage of the actor Yu. Yevsiukov are analysed and the genre and stylistic features of some of his roles in theatre and cinema are outlined. Conclusions. The article highlights important stages of the creative heritage of the actor Yu. Yevsiukov. The first period is the work at the Luhansk Regional Academic Ukrainian Music and Drama Theatre, where the foundations of his acting style were laid. Here the actor mastered the arsenal of traditional means of stage expression, mainly within the comedy genre. The second period is characterized by collaboration with the director O. Biliatskyi, during which new facets of the artist's talent were revealed, namely, the ability of his psychophysical apparatus to improvise. The third is the period of A. Vasyliev's directing, which contributed to the development of skills of "text drama" and "text improvisation" as a form of "living theatre".
\end{abstract}

Keywords: Yurii Yevsiukov; creative heritage; acting; performing style; theatre 